\title{
冬眠の心臟生理学
}

\section{—リス心筋の $\mathrm{Ca}^{2+}$ kinetics—}

\author{
近藤宣昭* \\ (*神奈川科学技術アカデミー・近藤「冬眠制御」プロジェクト) \\ $(*$ 三菱化成生命科学研究所)
}

\section{I 、はじめに}

ヒトは $0{ }^{\circ} \mathrm{C}$ 近い極度の低体温で生存するこ とはできない.生体の生理機構が正常に機能 できないからである. 生命維持に不可欠な心 臓の機能も $20^{\circ} \mathrm{C}$ 付近で異常をきたし停止す る. 常に $37^{\circ} \mathrm{C}$ の高い体温を維持する機構を獲 得した哺乳類と鳥類は，逆に低温に対する耐 性を退化させてしまったのだろうか？

このような哺乳動物の中にあって，冬眠動 物はある時期体温を $0{ }^{\circ} \mathrm{C}$ 近くまで低下させ生 存することができる.一見, 変温性に移行し たように見えるこの冬眠状態は調節性であり， 数 ${ }^{\circ} \mathrm{C}$ 体温を維持する機構が機能している. このことは，冬眠期に体温が低下するにもか かわらず，本質的には恒温性を維持している ことを示している.

このような冬眠状態では，毎分 400 回以上 あった心拍数は数回にまで減少する。しかし, 生体はなんら障害を受けることなく，一定の 生理状態を維持し生存することができる。こ のことから，冬眠動物の体内には低温に対す る適応機構が備わっていると考えられている。 特に，低温下で機能不全を起こす心臓は，低 温に対する適応がなされていなければならな い.この機構を研究するため, 冬眠動物であ るシマリスを用い，冬眠期および活動期の心 臓機能の電気生理学的, 薬理学的検討を行
なった。今回，これらの研究から得られた結 果を通して，冬眠哺乳動物の心臓における低 温耐性機構について報告する。

\section{II. 冬眠動物心筋の電気生理学的特性}

活動期と冬眠時のシマリスから摘出した心 室筋の電気生理学的特性を検討した。活動期 のシマリス心筋を電気刺激することにより得 られた膜活動電位は，モルモットなどの一般 的によく用いられる実験動物から得られたも のと基本的には同じで，最初に $\mathrm{Na}$ channel の活性化による速い一過性の脱分極が生ずる. それに続いて Ca channel の活性化による持 続的な脱分極（プラトー相）が引き起こされ， この脱分極はその後活性化される K channel を通る $\mathrm{K}^{+}$イオンの流出により元の静止電位 まで再分極される。

心筋の収縮を引き起こす細胞内 $\mathrm{Ca}^{2+}$ の増 加は，プラトー相での Ca channel を介した 細胞外からの $\mathrm{Ca}^{2+}$ 流入と,この一部を細胞内 に蓄えた筋小胞体からの $\mathrm{Ca}^{2+}$ 遊離により起 こされる、モルモット，ウサギの心筋の収縮 はこの Ca channel を介して流入する $\mathrm{Ca}^{2+} に$ 強く依存している。活動期のシマリス心筋の 収縮もこれらと同様であった。

一方，冬眠時のシマリスから摘出した心筋 における活動電位は，プラトー相の振幅が著 しく低下しており，Ca channel を介した細胞 
外からの $\mathrm{Ca}^{2+}$ 流入の減少が推測された. しか し, 他の活動電位の諸パラメーター（活動電 位最大振幅, 活動電位最大立ち上がり速度, 静止電位近くの活動電位持続時間, 静止電位) は活動期，冬眠時の間では変化が見られな かった（図 1 ).

これらの結果は, シマリスの心筋では収縮 を引き起こす $\mathrm{Ca}^{2+}$ の調節機構が, 冬眠時に著 しく変化していることを示唆している1).

\section{III. 冬眠時の心筋における Ca channel の変化}

Ca channel の阻害剤である nifedipine に より, 活動期のシマリス心筋の活動電位プラ トー相は顕著に抑制され，収縮もほぼ完全に 抑制された。しかし，冬眠時シマリスから摘 出された心筋では，プラトー相はほとんど影
響されず，収縮の抑制も軽度であった（図 $1)$.

さらに，おのおのの時期の心筋において， $\mathrm{Ca}$ channel を介して運ばれる $\mathrm{Ca}^{2+}$ を膜電位 固定法を用いて測定した結果，活動期の心筋 では大きい $\mathrm{Ca}^{2+}$ 電流が得られたが, 冬眠時の 心筋では $\mathrm{Ca}^{2+}$ 電流をほとんど観察すること ができなかった（図 2 ）。

これらの結果から，冬眠時には channel を 介した $\mathrm{Ca}^{2+}$ 流入がほとんど起こらなくなっ ていることが明らかになった。このことは， その時生ずる収縮が Ca channel を介したも の以外の $\mathrm{Ca}^{2+}$ で起こされることを示してお り，筋小胞体の関与を推測させた。

この推測を検討するため, 筋小胞体からの $\mathrm{Ca}^{2+}$ 遊離を消失させる薬物である ryanodine を用いた研究を行なった. Ryanodine は活動

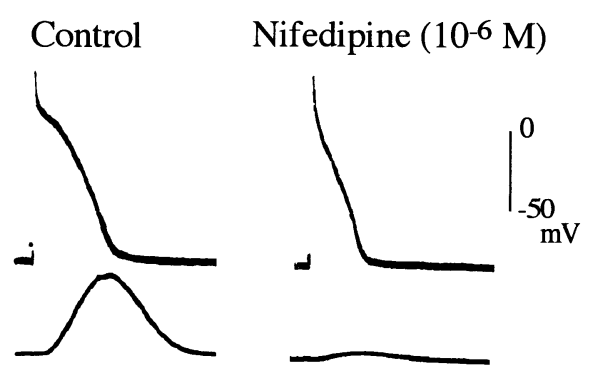

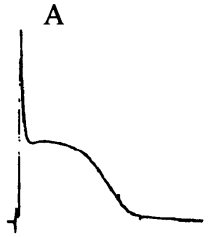

A

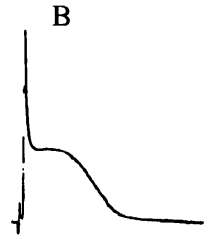

B

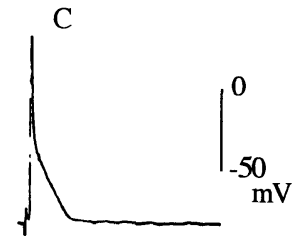

$\overline{100 \mathrm{msec}}$

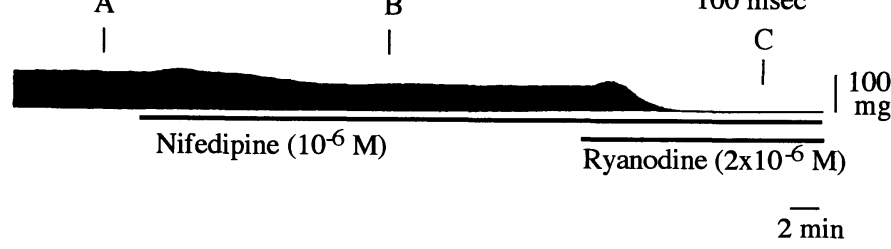

図 1 活動期（上図）と冬眠時（下図）のシマリス心筋乳頭筋標本におけ る膜活動電位と収縮に対する nifedipine と ryanodine の効果

実験は $30^{\circ} \mathrm{C}$ 栄養液中で行なった。 
期のシマリス心筋の収縮をわずかに抑制する が，プラトー相はむしろ延長させた。一方， 冬眠時の心筋の収縮とプラトー相は ryanodineによって完全に抑制された（図 1 ).

ここで得られた結果をまとめると, 活動期 のシマリス心筋の収縮は $\mathrm{Ca}$ channel を介す る $\mathrm{Ca}^{2+}$ 流入に強く依存しており, 冬眠時の心 筋の収縮は筋小胞体から遊離された $\mathrm{Ca}^{2+} に$ 依存する。このことは，冬眠時のシマリス心 筋では収縮のための $\mathrm{Ca}^{2+}$ が主に筋小胞体か ら供給されていることを示している1,2).

\section{K channelによる Ca channel の不 活性化}

では，冬眠時に観察される Ca channel を 介した $\mathrm{Ca}^{2+}$ 流入の減少はなぜ起こるのだろ うか.これには Ca channelの量的な減少と, 活性化の低下の 2 つの原因が考えられる.

冬眠時の心筋の活動電位プラトー相は $\mathrm{Ca}$ channel 活性化薬 isoprenaline により増大さ れたため，正常に機能する channel の欠如の ためではないことが示された。さらに，K channel 遮断薬である 4-aminopyridine を投 与することによりプラトー相の著しい増大が 観察されたことから,プラトー相の低下は $\mathrm{Ca}$ channel の量的な減少ではなく，一過性の K channel 活性化による再分極の促進によるも のと考えられた。この促進により Ca channel の活性化（活性化閾值がー $40 \mathrm{mV}$ 付近である ため，速い再分極が閾值より深くまで達する と Ca channel の活性化が十分起こらないと 考えられる) が抑制され，細胞外からの $\mathrm{Ca}^{2+}$ 流入が減少する ${ }^{3)}$.

この研究の中で, 冬眠時の活動電位プラ トー相を薬理学的手法により増大させた際, 収縮力が何ら変化しないという興味ある結果 を得た。このことは, 膜興奮と収縮の連関が 冬眠時の心筋で変化していることを示してい る.

A. Ca current

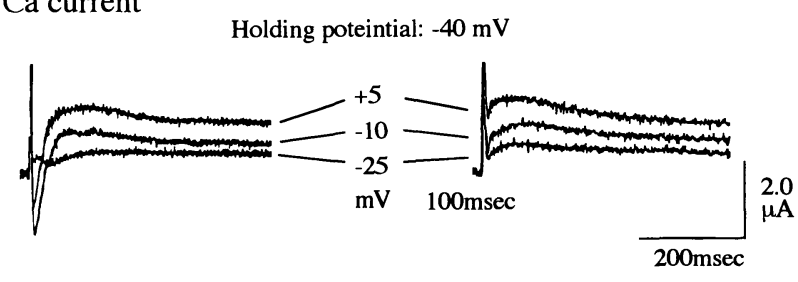

B. I-V curve
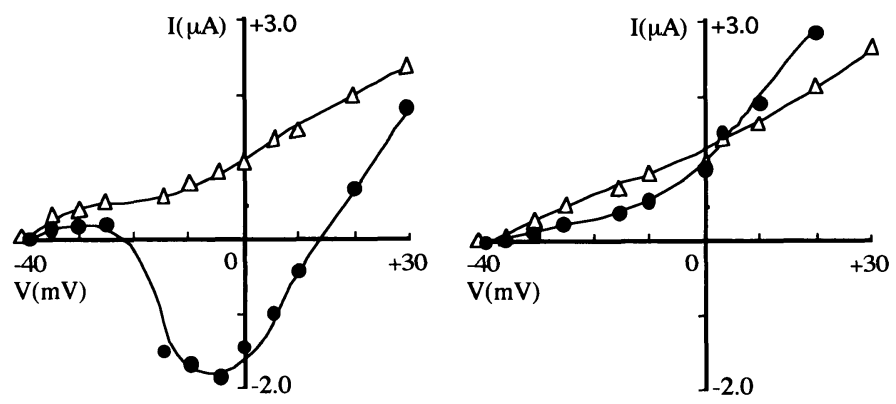

図 2 活動期（左図）と冬眠時（右図）のシマリス心筋乳頭筋標本におけ 了膜電位固定実験

$\mathrm{A}$ : 保持電位 $-40 \mathrm{mV}$ 加種々の電位 $(-25,-10,+5 \mathrm{mV})$ に電位固定し たときに流れた $\mathrm{Ca}$ 電流の記録. B : A で得られた結果をもとにした $\mathrm{Ca}$ 電流（）とK電流 $(\triangle)$ の電流-電圧曲線 


\section{$\mathrm{V}$. 筋小胞体の機能変化}

冬眠時心筋において示唆された興奮一収縮 連関の変化を調べるため, Ca channel 活性化 薬 isoprenaline と筋小胞体からの $\mathrm{Ca}^{2+}$ 遊離 抑制薬 caffeine を用いて検討した. Caffeine は ryanodine と異なり, 筋小胞体への $\mathrm{Ca}^{2+}$ 取 り込みを抑制することにより $\mathrm{Ca}^{2+}$ 遊離を減 少させる.

Isoprenaline がプラトー相を著しく増大さ せるにも関わらず収縮力の増強を起こさない という矛盾は caffeine の前処置により解消 された. Caffeine を投与すると冬眠時心筋の プラトー相は ryanodine の場合と同様に完 全に抑制されたが，引き続き isoprenaline の 追加により，抑制されたプラトー相は著しく 増大され，同時に収縮力も増強された。これ らの isoprenaline の作用は $\mathrm{Ca}$ channel 遮断 薬である nifedipine により完全に抑制され た。このことは，プラトー相の増大により細 胞内へ流入した $\mathrm{Ca}^{2+}$ が収縮タンパクに達し 収縮を引き起こしたことを示している（図 3 ). すなわち, caffeine が筋小胞体への $\mathrm{Ca}^{2+}$ 取り込みを抑制した結果，isoprenaline によ り細胞内へ流入した $\mathrm{Ca}^{2+}$ が筋小胞体に捕捉 されず収縮タンパクに達し収縮を起こしたと
考えられる4).

冬眠時の心筋に，このような興奮一収縮連 関が観察されるためには, 筋小胞体の $\mathrm{Ca}^{2+}$ 取 り込み能が著しく増大していなければならな い.すなわち，筋小胞体への $\mathrm{Ca}^{2+}$ 取り込みを 増大させることにより細胞内へ流入した $\mathrm{Ca}^{2+}$ を効率よく捕捉し, 収縮タンパク質への $\mathrm{Ca}^{2+}$ 供給を低下させていると考えられ $\Xi^{2,4), 6)}$.この考えは, 心筋から調整した筋小胞 体膜を用いた Belke ら ${ }^{5)}$ の実験によって裏 付けられた。

\section{VI. 冬眠時の心筋における低温耐性機構}

以上の結果から，冬眠時の心筋では細胞膜 の Ca channel は興奮時にもほとんど活性化 されず, 筋小胞体の機能が増大されているこ とが示唆された。

低温下に置かれた心筋では channel やNaK ATPase の kinetics が低下すると考えら れる.脱分極により開口した Ca channel の 不活性化は起こり難くなり, $\mathrm{Na}-\mathrm{K}$ ATPase の活性低下は細胞内 $\mathrm{K}^{+}$濃度の低下を引き起 こし膜の脱分極を促進する．この結果， $\mathrm{Ca}$ channel の開口時間は延長され, 細胞内に $\mathrm{Ca}^{2+}$ 過剩負荷が起きる. 細胞内に高濃度の $\mathrm{Ca}^{2+}$ が蓄積すると, 心臓は収縮位停止を起こ
A. Control
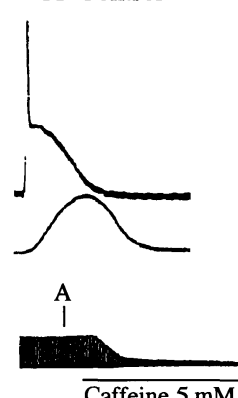

B. Caffeine

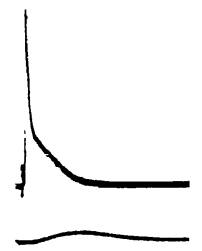

C

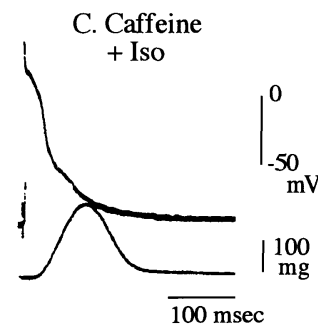

$100 \mathrm{msec}$ $\mid \begin{array}{r}200 \\ \mathrm{mg}\end{array}$

図 3 冬眠時のシマリス心筋乳頭筋標本における膜活動電位と収縮に対 する caffeine, isoprenaline (Iso), ryanodine と nifedipine の効果 
し機能不全に陥る.ミトコンドリアにも $\mathrm{Ca}^{2+}$ の過剰蓄積が生じ機能障害を起こす。細胞質 の phospholipase は活性化され膜脂質の加水 分解を起こし細胞膜を破壊する7). ほかにも, $\mathrm{Ca}^{2+}$ の持つ多くの細胞毒性が現われ, 最後に は細胞は壊死を起こすと考えられる。

冬眠時に生ずる Ca channel の活性化の抑 制は細胞外からの過剩な $\mathrm{Ca}^{2+}$ 流入を防止し, 筋小胞体機能の増大は細胞内の $\mathrm{Ca}^{2+}$ 過剰負 荷を低減する.このような $\mathrm{Ca}^{2+}$ 調節機構の変 化は, 細胞を Ca 障害から防御するために重 要な働きをしているものと思われる.さらに, 筋小胞体に蓄積された $\mathrm{Ca}^{2+}$ は, 冬眠時の細胞 膜を介する $\mathrm{Ca}^{2+}$ 流入の減少を代償し, 収縮に 十分な $\mathrm{Ca}^{2+}$ 収縮タンパクに供給するため にも重要な働きをしているだろう。

この研究で得られた結果は, 冬眠動物の心 臓が低温下で正常に機能するために重要な機 構を提示している.心臓だけではなく他の組 織の低温耐性機構を研究する上でも重要な知 見となるだろう ${ }^{7)}$.さらに, 心筋細胞の $\mathrm{Ca}^{2+}$ 調 節機構が同一個体内で変化する事実は生体内 に調節性の適応機構を持っていることを示し ており, 生体の適応機構の解明にも新たな道 を開くことが期待される ${ }^{8)}$.

\section{文献}

1) Kondo N, Shibata S : Calcium source for excitation-contraction coupling in myocardium of nonhibernating and hibernating chipmunks. Science $225: 641 \sim 643,1984$

2 ) Kondo N : Excitation-contraction coupling in myocardium of nonhibernating and hibernating chipmunks myocardium : Effects of isoprenaline, a high calcium medium and ryanodine. Circ Res 59: 221 228, 1986

3 ) Kondo N : Excitation-contraction coupling in hibernating chipmunks myocardium. Experientia $42: 1220 \sim 1222,1986$

4) Kondo N : Comparison between effects of caffeine and ryanodine on electromechanical coupling in myocardium of hibernating chipmun- ks : Role of internal Ca stores. Br J Pharmacol 95 : 1287 1291, 1988

5 ) Belke DD Z-Q, Milner RE, Wang LCH : Seasonal variations in the rate and capacity of cardiac SR calcium accumulation in a hibernating species. Cryobiol 28: 354 363, 1991

6) Zhou, Z-Q, Liu B, Dryden WF, Wang LCH : Cardiac mechanical restitution in active and hibernating Richardson's ground squirrel. Am J Physiol 260 : R353-R358, 1991

7 ) Frerichs KU, Kennedy C, Sokoloff L, Hallenbeck JM : Local cerebral blood flow during hibernation, a model of natural tolerance to "cerebral ischemia". J Cereb Blood Flow Metab. 14: 193 205, 1994

8 ）近藤宣昭：冬眠物質一一冬眠に特異的な生体内 因子一脳と精神の医学 $4 ： 369 \sim 374,1993$

\section{質疑応答}

座長 桑澤清明 (東京都立大学) 長坂（立川相互病院）：骨格筋では収縮に $\mathrm{Ca}$ 流入はいらないといわれている. 冬眠動物の 骨格筋ではどうか.

近藤：骨格筋での研究も既にあり, 今回報告 した心蔵と同様，冬眠時には，筋小胞体の $\mathrm{Ca}^{2+}$ 取り込み能が増大するという報告があ る.

杉本 (関東中央病院)：細胞収縮が SR 依存性 になるとなぜ冬眠に都合がよいか.

近藤：冬眠中は数 ${ }^{\circ} \mathrm{C}$ で体温が下がるので $\mathrm{Ca}$ チャネルが $37^{\circ} \mathrm{C}$ 体温時と同様に開閉する なら, 速度は当然著しく遅くなる.チャネル の閉じる速度の低下は, 多大の $\mathrm{Ca}^{2+}$ の流入を 招き, 細胞内 $\mathrm{Ca}^{2+}$ の排除機構（筋小胞体や細 胞膜の Ca ATPase おょび $\mathrm{Na}-\mathrm{Ca}$ 交換機 構）の低温による機能低下とあいまって，細 胞内 Ca のオーバーロードを生じ, 心筋細胞 の機能不全が起こる.一方, Ca チャネルが抑 制され，筋小胞体による $\mathrm{Ca}^{2+}$ 調節が主体にな れば, 細胞内 $\mathrm{Ca}$ のオーバーロードを回避で 
き，冬眠の低体温下でも心臓が正常に機能で きる。

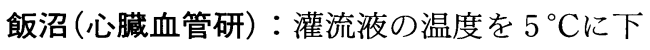
げると APD の延長が生じるのではないか. 冬眠状態ではその点でも保護されているか. 近藤：低温はすべてのチャネルの kinetics を遅くし, APD の延長が生ずる.この延長が Ca チャネルの開口増加を生ずるかどうかが 問題である。これは実際に実験しなければ分 からないが, 冬眠期の心筋細胞では早期の $\mathrm{K}$ チャネルの強い活性化が Ca チャネルを抑制 しているので, 低温下での K チャネルの活性 化が特に抑制されやすいとは考え難く,さら に, $\mathrm{Ca}$ チャネルが開く引き金になる $\mathrm{Na}$ チャ ネルによる脱分極も低温下で著しく抑制され るので, Ca チャネルの開口はより難しくな る. 冬眠時の心筋細胞は低温でも演者の研究 結果と同様に機能し, Ca オーバーロードから 保護されると考えられる。

渡部（藤田保健衛生大）：温度の影響を除くた めに $30^{\circ} \mathrm{Cで}$ 実験されたのはわかるが, 実際の 冬眠期には温度は低いわけであるから例えば 活動期の心臓から心筋細胞レベルで温度を $7^{\circ} \mathrm{C} 5{ }^{\circ} \mathrm{C}$ にげるとその細胞はどうなるか. 活動期の心筋の電流電圧曲線には, はっき り内向き電流が得られているが，その細胞を 低温にするとその電流はどうなるか. 最終的
には温度による代謝の変化まで調べる必要が あると思う。

近藤：実際にその様な低温での保存も行なっ たが, 冬眠期の心臓から摘出した乳頭筋標本 は一週間ほど収縮機能を保持した。

活動期の心筋の低温時の内向き電流につい ては測定していないが, 低温時の活動電位波 形と収縮曲線（プラトー相の顕著な延長と, 収縮力と持続時間の著しい増大）から著しく 増強されると推定される。

エネルギー代謝の研究は多く, ミトコンド リアの酸化的リン酸化に関わる酵素は低温下 でも活性が保持される。演者の実験からも anoxia には抵抗性が高いといえる.個体の冬 眠現象には，あらゆる生理反応が関係してい るはずで, 演者が発見した $\mathrm{Ca}^{2+}$ 調節機構の変 化もその一部である.

桑澤（東京都立大）：Na-K ATPase あるい は電気発生 $\mathrm{Na}$ ポンプの働きは, 冬眠中と非 冬眠中の動物の心筋で異なるか.

近藤：Na-K ATPase の研究は心筋よりも 赤血球でよく研究されている. 冬眠中のもの は低温でも高い活性を保持し, これにより低 温下でも細胞内の $\mathrm{K}^{+}$の保持と $\mathrm{Na}^{+}$の排除が 行なわれ, 細胞内イオン濃度が正常に保たれ る. 